\title{
Main Anthropogenic Impacts on Benthic Macrofauna of Sandy Beaches: A Review
}

\author{
Afghan Afghan, Carlo Cerrano ${ }^{\circledR}$, Giorgia Luzi, Barbara Calcinai, Stefania Puce, \\ Torcuato Pulido Mantas, Camilla Roveta $@$ and Cristina Gioia Di Camillo * $\mathbb{B}$ \\ Department of Life and Environmental Sciences, Marche Polytechnic University, 60131 Ancona, Italy; \\ a.afghan@pm.univpm.it (A.A.); c.cerrano@staff.univpm.it (C.C.); delfina944@hotmail.com (G.L.); \\ b.calcinai@staff.univpm.it (B.C.); s.puce@staff.univpm.it (S.P.); t.pulido@pm.univpm.it (T.P.M.); \\ c.roveta@pm.univpm.it (C.R.) \\ * Correspondence: c.dicamillo@staff.univpm.it
}

Received: 7 April 2020; Accepted: 29 May 2020; Published: 3 June 2020

\begin{abstract}
Sandy beaches provide several ecosystem services such as coastal protection and resilience, water filtration and nutrient mineralization. Beaches also represent a hub for social, cultural and economic relationships as well as educational activities. Increasing urbanization, recreational activities and mechanical beach cleaning represent major anthropogenic disturbances on sandy beaches leading to loss of biodiversity as well as good and services. Information about the impacts of anthropogenic pressures on benthic macrofaunal communities could be useful to assess the environmental status of sandy beaches and to promote a sustainable use of beach ecosystem. Here, scientific articles about three major anthropogenic impacts on sandy beach macrofauna were reviewed to provide the state of knowledge about these impacts, to highlight gaps, to supply considerations about the methodologies and the used indicators and to give insights for future studies. The stressors considered in our review are: 1) trampling, 2) breakwater barriers, 3) mechanical beach cleaning. This review underlined that there are few studies regarding individual human disturbances on sandy beach macrofauna and specifically, there is a lack of sufficient indicator species for the assessment of such stressors. Similarly, the researches have covered specific regions, highlighting the need for such studies in other parts of the world. In particular, the impacts of breakwater barriers on surrounding communities has been found to be given less attention in the literature and there is enough that could be explored.
\end{abstract}

Keywords: sandy beach; macrofauna; macrobenthos; benthic; human impacts; beach cleaning; trampling; breakwaters

\section{Introduction}

Natural sandy beaches provide key ecosystem services such as balancing transport, storage of sand, increasing coastal protection and resilience [1-3]. Sandy beaches also offer water filtration [4], shape energy fluxes between biotic and abiotic components [5], modulate bentho-pelagic exchange into sediments [6] and allow the establishment of trophic relationships among marine and dune ecosystems [7]. Besides their ecological value, beaches represent a hub for social, cultural and economic relationships [8,9] as well as educational activities [10,11].

Due to valuable goods and services of beaches and their vulnerability to erosion, flooding and overexploitation of natural capital, the European Commission launched a proposal for a Directive for maritime spatial planning and integrated coastal management [12], in order to promote "the sustainable growth of maritime and coastal activities and the sustainable use of coastal and marine resources". 
Sandy beaches are used mainly for tourism and recreational activities [13]. These coastal areas generate revenue and support the economic system by entertaining millions of visitors [14]; however, a rapid and intense anthropogenic development has been causing degradation of coastal habitats and loss of ecosystem services [7].

There is an increasing pressure on shoreline due to coastal engineering [15-17], and several other anthropogenic activities like trampling, mechanical beach cleaning and motor vehicle traffic that impact the sandy beach environments at different spatial and temporal scale [18-21]. Besides the vital role of sandy beaches in modern society, the ecological and socioeconomic impacts are not investigated appropriately [22]. Anthropogenic changes in sandy beaches had been there since long time and are projected to become even more intense in coming decades [7]. These activities could potentially alter habitat features and macrofaunal community structure resulting in the loss of biodiversity [23], loss of ecosystem services and difficulties in facing climate crisis. Benthic macrofauna living in soft substrates plays a pivotal role in particles reworking $[24,25]$, nutrient cycling $[24,26]$ and serving as food for other organisms $[27,28]$.

Ecological status of submerged sandy beaches can be assessed by analyzing the composition and abundance of macrofauna and through the elaboration of biotic indexes [29,30]; however, these indexes put in evidence the sensitivity to organic enrichment and they do not consider effects of other forms of impact.

Macrofauna living in the intertidal zone can be particularly vulnerable to beach activities [13,31-33]. In recent decades, there are some studies based on understanding the response of macrofaunal communities and populations towards physical disturbances [34-36].

Community structure of macro-, meio- and microfauna hosted in beach environments is influenced by the interaction of several physico-chemical factors such as sand granulometry, mineralogy and tides or beach exposure [7,37-39], suggesting that alteration of natural beach dynamics due to human pressure could affect ecological traits of these organisms and overall functioning of beach ecosystem [40].

The main objective of our study is to review researches on three kinds of stressors affecting the integrity of sandy beach macrofaunal communities: 1) trampling, 2) breakwaters, 2) mechanical beach cleaning. Moreover, we showed temporal trends of these studies and their geographical distribution. We have focused on those relevant impacts on beach macrofauna which are scarcely considered by scientific community. In particular, we did not evaluate the studies regarding impact of beach nourishment on beach macrofaunal communities because this topic has been the subject of numerous studies and reviews [41-45].

\section{Materials and Methods}

An extensive bibliographic search was conducted on Elsevier's Scopus database using keywords in the search engine selecting the option "Article title, Abstract, Keywords" limiting it to the cut-off date of 1 September 2019 (Figure 1). The document type chosen in search strategy included 'article', 'congress paper', and 'review'. In the first step, the keywords searched were, namely: 'trampling', 'breakwater or coastal defense structure' and 'mechanical beach cleaning'. In order to look for studies on breakwaters, we also added the keyword 'coastal defense structure' as initial studies had addressed the breakwaters as 'coastal defense structures'. Since coastal defence structures also include other structures such as seawalls and jetties etc., we chose the articles that were based on breakwaters only.

In the second step, the results obtained were refined by searching 'macrofauna OR macrobenthos' within the obtained articles. The higher number of articles in the first step was because the articles were not restricted to biology or ecology and rather, related to all disciplines. In the third step, the articles were further screened by reading the titles and abstracts followed by the exclusion of the articles that were irrelevant to our objective. In the fourth and last step, the remaining articles were thoroughly screened and the ones eligible for our study were considered. Important criteria for considering articles was that the articles must be in English language, accessible through online databases and the article or part of article must be clearly addressing the impacts of at least one of the three mentioned stressors 
on macrofaunal communities (i.e., trampling, breakwater barriers and mechanical beach cleaning). Moreover, it was made sure that all the scientific articles we have considered, were focused on sandy beaches only. The articles relating to rocky beaches or reefs were excluded. Additionally, the references in the selected papers were used to find articles that we could have missed in our searching strategy. A stepwise sketch of the searching strategy is given as Figure 1.

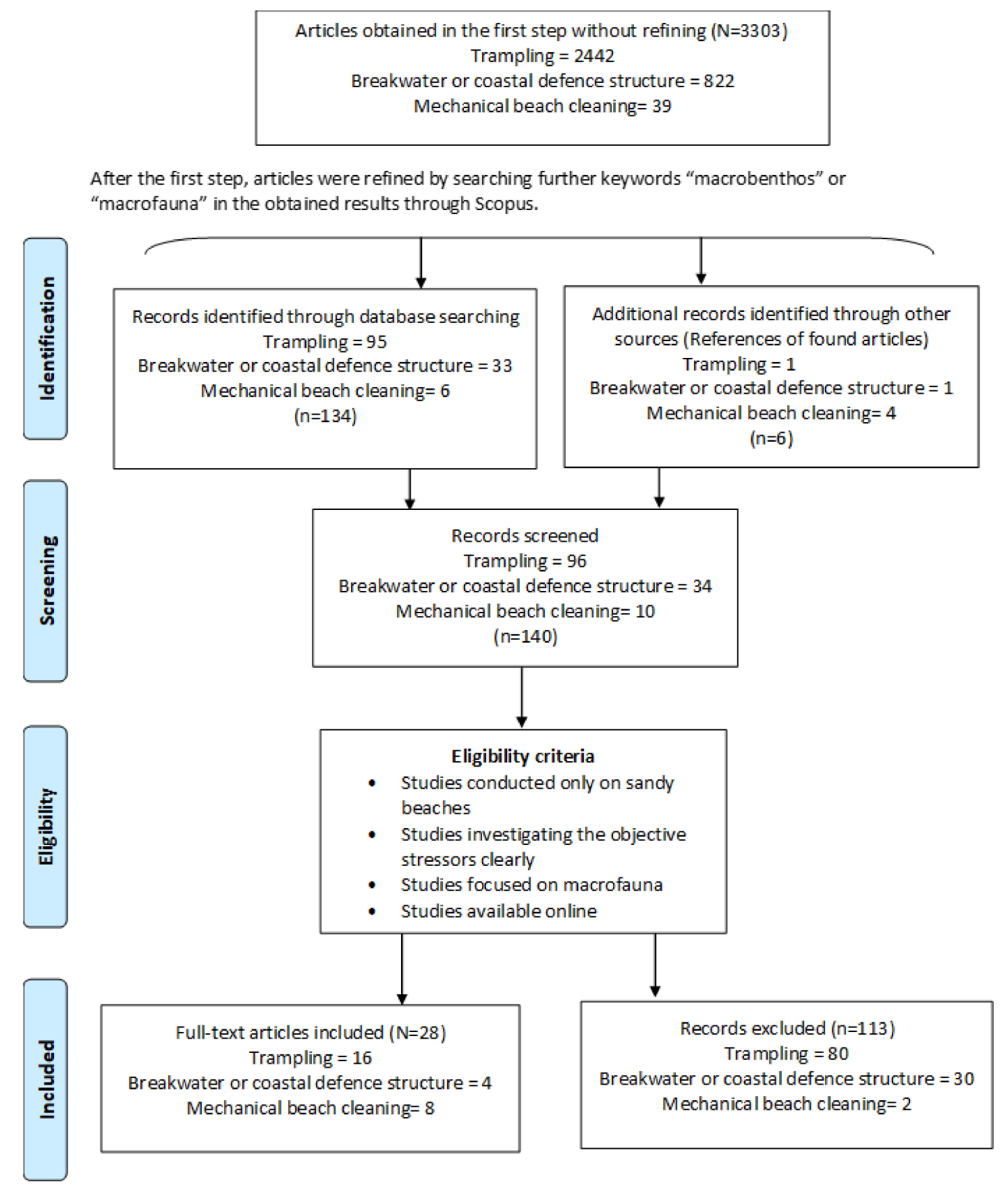

Figure 1. A flow chart illustrating steps for obtaining scientific articles in English language about impacts on sandy beach communities from Scopus search engine.

The studies considered were assessed based on the type of methods utilized, the use of indicators, geographical location, sampling equipment and number of beaches covered by each study. Additionally, temporal distribution of studies as well as period of the year in which the studies were conducted were considered in the assessment process. 


\section{Results}

Initially, 2442 articles were found for 'trampling', 822 for 'breakwater or coastal defence structure', and 39 for 'mechanical beach cleaning'. After refining the articles by inducting further keywords 'macrofauna OR macrobenthos' in the obtained results, the number of articles was 95 for trampling, 33 for breakwaters and 4 for mechanical beach cleaning. The articles were further refined by reading at least the title and abstract. The articles that were not in relevance with our objective were removed. Additionally, 1 article was found for trampling, 1 for breakwater and 4 for mechanical beach cleaning by searching through references of obtained articles. In the end, 28 articles were included where 16 were on trampling, 4 on breakwater and 8 on mechanical beach cleaning. The following paragraphs will illustrate temporal and geographical distributions of the considered papers; all articles details (publication year, Authors, title, DOI, applied methodologies, indicator species and sampling frequency) are available in Table S1.

\subsection{Temporal Distribution of the Selected Studies}

Figure 2 shows the studies on considered three forms of impact on macrofauna through the years. The oldest two articles found on the trampling impacts on sandy beach macrofauna were published before 2000 (1997 and 1998, citations in Table S1). Afterwards, no articles could be found until 2006, while six articles were published between 2006 and 2010, four between 2011-15 and further four between 2016 and 2019.

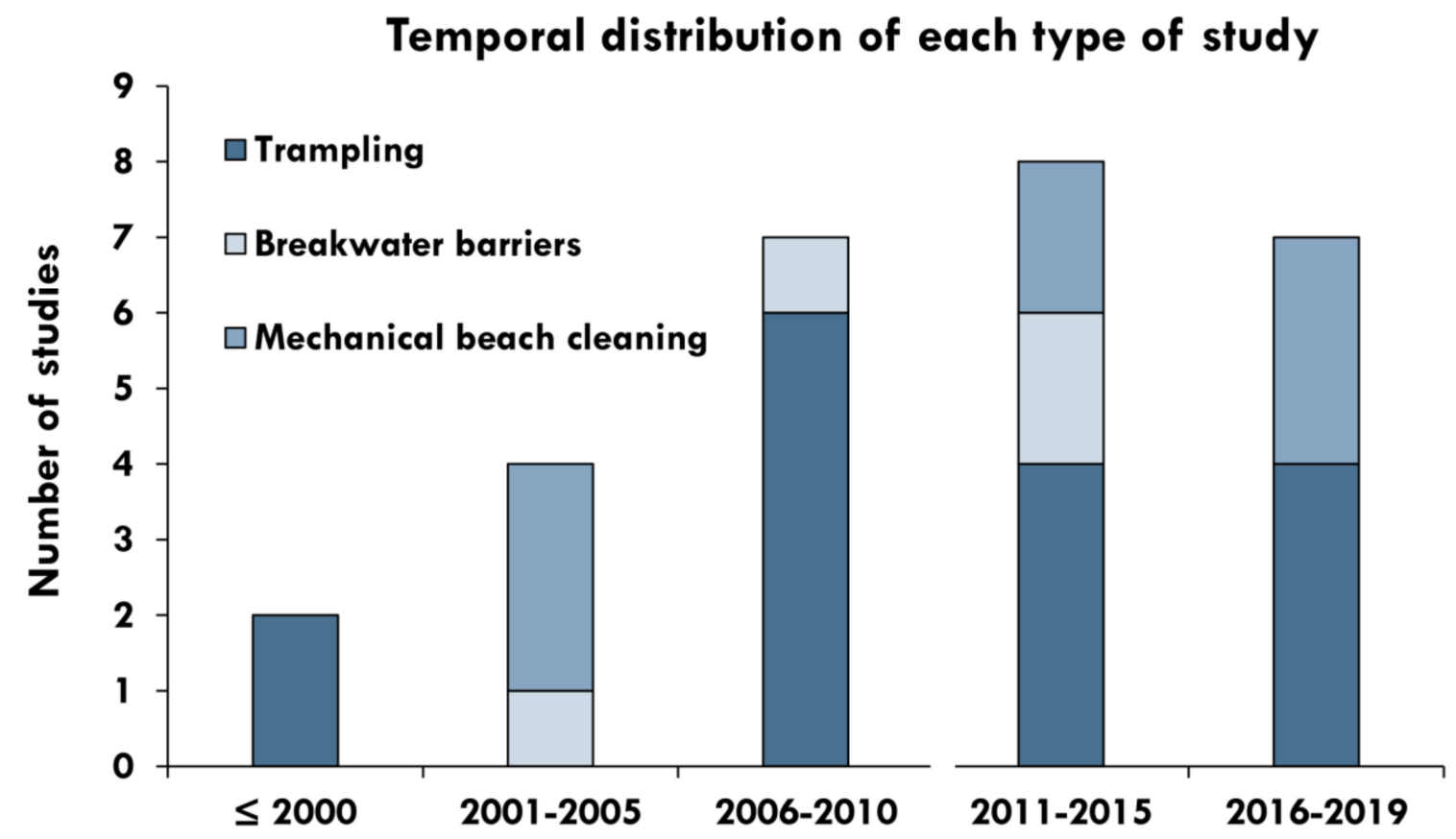

Figure 2. Histogram showing temporal distribution of studies about trampling, breakwater barriers, mechanical beach cleaning impacts.

Out of the four studies on the impacts of breakwaters, the first one was published in 2001-2005, the second in 2006-2010 and the other two in 2011-2015.

The third anthropogenic impact considered was 'mechanical beach cleaning', for which eight articles were found in relevance with the objective. The first three articles were found between 2001 and 2005, two in 2011-2015, and three in 2016-2019. 


\subsection{Geographical Distribution of Studies}

Articles covering more than one country are counted for all the countries that were included in the study. Out of 28 studies, most of the papers regarding all the three stressors were conducted in four countries i.e., Italy (6), Australia (5), Brazil (5) and Spain (4), while the remaining studies were performed in South Africa, Scotland, Sweden (2), England, Greece, South Korea, the Netherlands and the USA (1) (Figure 3A).

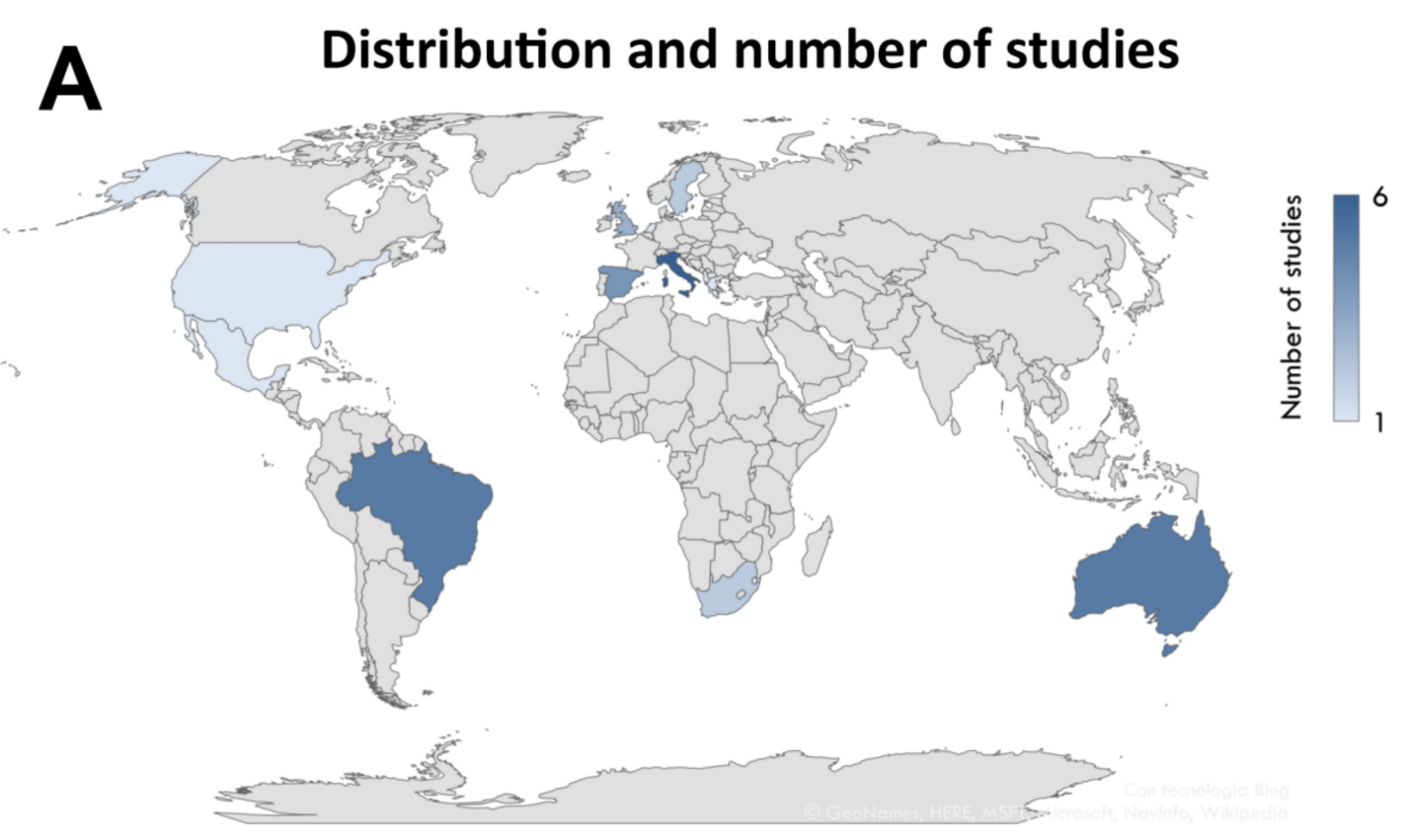

\section{B Geographical distribution of each type of study}

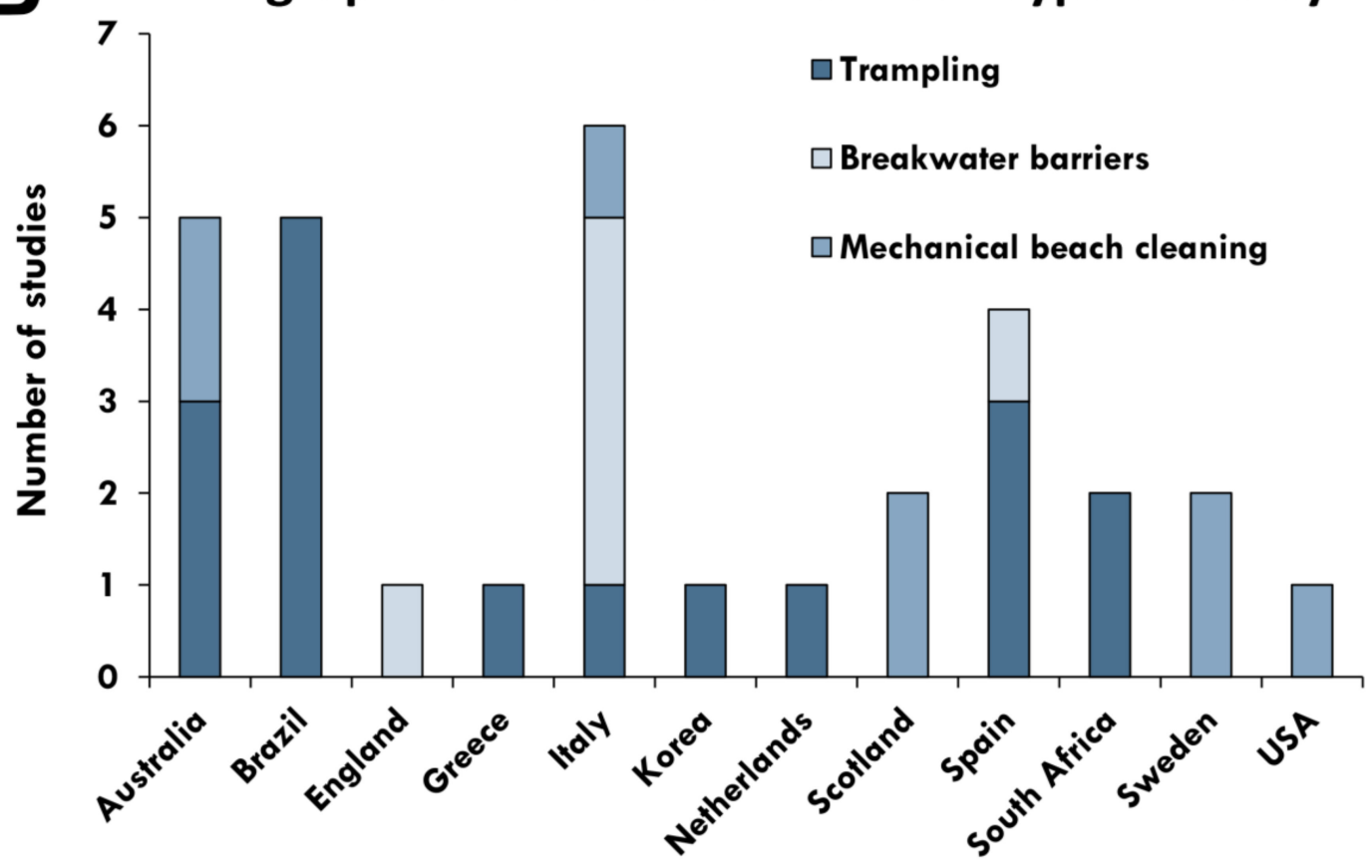

Figure 3. (A) Map of distribution and volume of all studies on the three considered forms of impact. (B) Geographical distribution of studies for each impact typology. 
Concerning the typology of the gathered studies (Figure 3B), studies on trampling impacts were carried out in Brazil (5/5), Australia (3/5) and Spain (3/4); one of these studies (Table S1) was jointly conducted in Brazil and Spain.

Articles about breakwaters were published in Italy (4), Spain (1) and England (1) only.

Concerning the mechanical beach cleaning impacts, there are two articles from Australia, Scotland and Sweden and one from Italy. Italy was the only country were all the three kinds of impact were studied.

In total, seven articles could be found covering the Mediterranean basin, where four of the articles focused on the impacts of breakwater barriers. In the remaining, two articles were about trampling, while only one was about mechanical beach cleaning impacts on macrofauna. Regarding trampling impacts, one study was carried out along the Italian side of the Tyrrhenian coast (Western Mediterranean), while the one in Greece was performed in the South Aegean Sea (Eastern Mediterranean). Among the studies on breakwater barriers' impacts, one was found on Tuscan coast (Tyrrhenian Sea, Italy), two on the Italian Adriatic coast and one covering together England, Spain and Italy. The only study about mechanical beach cleaning was conducted in Italy (Tuscany) on the Tyrrhenian coast.

\subsection{Methods of Study and Considered Taxa}

In most of the considered studies, the sampling activities were conducted two to six times where the sampling was either seasonal or following Before-After impact design. Additionally, one study had 13 sampling sessions while another had 15 . Five of the studies had used experimental stressors before sampling, which could explain the sudden response of target species towards the impacts, but for long-term impacts, seasonal or other long-term sampling could be more appropriate. In case of before and after impact sampling, the time period of the year could also be potentially crucial. While other sampling gears used have more reliability, methods such as burrow counting for crabs, pitfall traps or arthropod traps may not be the most appropriate tools to evaluate the aforementioned impacts.

The methods used by studies regarding trampling impacts on macrofauna mainly included i) trapping crustaceans (3), ii) direct on-site counting of organisms/burrows (3) and iii) collection of sediments with macrofauna from a delimited squared area (5) or by using cylindrical corers (5).

While most of the studies (9) covered the overall macrofaunal community, crustaceans (amphipods, crabs) were found to be used as indicator species in six studies; only one study considered a gastropod species (Tritia neritea).

In case of breakwater barriers (four studies, Table S1), all the researches employed Van Veen grabs as the main equipment for collection of benthic macrofauna. In one study, PVC corers were used as well at some sites. The Van Veen grabs used were ranging between $270 \mathrm{~cm}^{2}$ to $600 \mathrm{~cm}^{2}$, while all the studies used overall macrofaunal community as indicator. The criteria considered by different studies to evaluate the impact of breakwaters were the distance from breakwater, landward/seaward side of the breakwater or the position of sampling site from breakwater.

In case of mechanical beach cleaning impacts (eight studies, Table S1), the sampling materials and methods used by researchers were corers (three articles), counting burrows/organisms (3) and an aspirator (1). The corers used in all studies were having a height from 10 to $20 \mathrm{~cm}$, while one article [14] among the total eight was a review paper.

Two studies had used a single indicator species i.e., ghost crab (Ocypode cordimanus) and sand hopper (Talitrus saltator), while the rest of the studies were based on overall macrofaunal community (Table S1). Among the organisms most affected by mentioned forms of impact (Table S1), the highest number of species belonged to polychaetes, bivalves (in particular, the Cardida order), amphipods and isopods (31, 21, 17, and 7, respectively; Figure 4A,B). Overall, $42(46 \%)$ species considered in the reviewed studies were found to be affected by trampling, 37 (41\%) by breakwaters and $12(13 \%)$ by mechanical beach cleaning (Table S1). While amphipods were especially used for assessing the impact of trampling, bivalves were mainly considered for the beach cleaning impact. Only one species 
has been used for assessing all the three forms of impact (the polychaete Hediste diversicolor); while, the bivalve Limecola baltica (order Cardida) and the amphipod Talitrus saltator were considered both for trampling and mechanical beach cleaning.

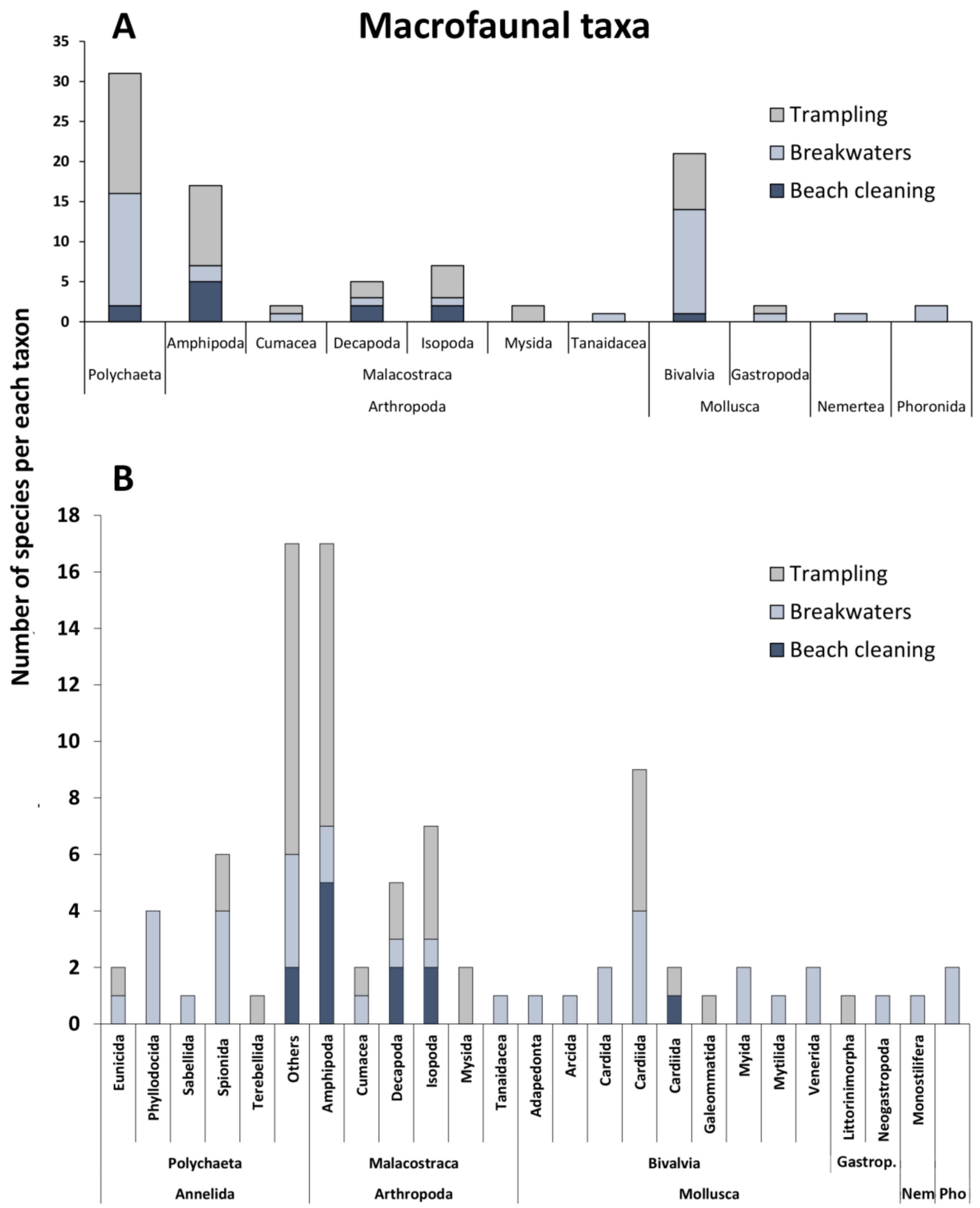

Figure 4. Main taxa found to be affected by trampling, breakwater barriers and mechanical beach cleaning. (A) Most commonly found taxa are polychaetes, bivalves and crustaceans. (B) Orders including the highest number of vulnerable species are Spionida (class Polychaeta), Amphipoda and Isopoda (Malacostraca) and Cardida (Bivalvia). 


\section{Discussion}

\subsection{Studies on Trampling}

Trampling related to the recreational activities is one of the main threats faced by macroinvertebrates and their predators [46]. Most articles regarding trampling impacts on macrofauna (Table S1) have reported a decrease in abundance of macrofauna, even if not all species were affected at the same level, since certain species are more vulnerable than others [34]. Out of the studies we found, only one concluded that trampling did not have a significant impact on indicator species, attributing it to the sustainable use of the beach without violating the carrying capacity [47]. The first study that included impacts of beach activities on macrofaunal communities was conducted in Chile by [48], but it did not separate trampling from other recreational activities.

Both the first studies on trampling impacts, [49] and [50] were conducted in South Africa. Wynberg and Branch [49] found that the trampling influence-resulting from bait collection for sand-prawns (Callianassa kraussi)_lasted not less than six weeks and the prawn population could be seen fully recovered by 32 weeks. Similarly, Moffet et al. [50] reported a different response of different species to changing intensity of trampling (see Table S1). Certain species have the ability to apply peculiar behavior to limit the impact: for example, the bivalve Donax serra is able to move to a depth where the effects of trampling due to walking cannot cause damages; however, it was reported to be significantly affected (i.e., shells were damaged) by vigorous trampling during games like volleyball. Another bivalve, Donax sordidus and the isopod Eurydice longicornis were found to be more resistant since they were affected only at high intensities of trampling [50]. Veloso et al. [34] supported the same idea of different responses from different species and, in their study conducted on different beaches with almost the same morphodynamics, they reported that both decapods and amphipods were vulnerable taxa to trampling.

In the Netherlands, different responses of macrofauna to trampling were documented when temporal stages of life cycles were considered [51]. The population dynamics of the bivalves Limecola balthica and Cerastoderma edule were altered and experienced a negative impact in adult specimens, potentially because they were killed or buried through footsteps. In contrast, the recruitment of juveniles of L. balthica got enhanced probably because larval recruitment was always high in the considered period, while no effect was reported for larvae/juveniles of C. edule. According to the authors, in the long terms, L. balthica could replace C. edule with relevant changes in ecosystem functioning.

The impact of trampling was demonstrated by Schlacher and Thompson et al. [52] on macrofaunal communities in a sandy beach in Queensland, Australia. Significant differences among the impacted (i.e., accesses to beach) and control plots were found on lower shore (i.e., the shore at the lower limit of the tide) as out of nine common species, eight were found to be less abundant at the impacted sites with a decline in mean abundance from $-90 \%$ (Urohaustorius halei) to $-12 \%$ (Glycera sp. 1), contributing to an $84 \%$ dissimilarity among impacted and controlled sites on SIMPER analysis. On the other hand, the difference in total abundance at impacted and controlled sites at upper shore (i.e., the shore at the upper limit of the tide) was not significant. The variation on lower shore was attributed to the different sensitivity levels of species occupying two portions of the beach.

A study in Cadiz bay, Spain reported different responses of different organisms towards human trampling, assessed before and after the tourist period [23]. The study investigated macrofaunal assemblages at three sectors with different trampling intensity in three beaches. In all the sectors, during the tourist period, the contribution of crustaceans faced a decline, while that of polychaetes got increased.

Schlacher et al. [53] also documented the trampling influence on upper shore macrofauna through experimental trampling in Venus Bay, Australia. Surface-active community structure was found to be changed while the number of species declined from 28 to 22 as trampling intensity increased with rare species facing a significant decline. The same kind of negative impact of trampling was found by Machado et al. [21] by assessing the trampling effect on two beaches with urbanized and non-urbanized 
sectors at Rio de Janeiro, Brazil. However, the community structure between the two beaches was different, which could possibly be due to the different level of tourism pressure, mainly trampling. The study gives very useful information about the sensitivity of certain species, such as the amphipod Atlantorchestoidea brasiliensis, the polychaetes Hemipodia californiensis and Scolelepis sp., which could be good indicators for analyzing recreational activities. Reis and Rizzo [13] investigated the influence of trampling by comparing two beaches, one with intense use (Urca beach) and the other (Fora beach) with restricted use. The overall species density in sediments was found to be higher at Urca beach, probably because disturbances other than trampling (such as beach cleaning) could have an impact on macrofauna communities in Fora beach.

The sand hopper (Talitrus spp.) has been used as an important indicator to evaluate trampling effects [35,36,54]. Veloso et al. [36] compared urbanized sites with higher number of visitors to protected ones, both in in Brazil and Spain, and found significantly higher density of talitrid amphipods at protected sites. Minor seasonal fluctuations in density were found in Brazilian sites, while higher seasonal variation was found in Spanish sites with no increase in Talitrus amphipods, even when the beach was not visited anymore in winter. The same negative relation was found in another study, since the number of amphipods was highest at lowest tourist pressure, while lowest at highest tourist pressure [54]. This is the only study which has an assessment based on three years for five out of eight considered sites. Although the author did not exclude the possibility of other influences that could play a role in declining the abundance of sand hoppers, they demonstrated with a trampling simulation experiment that only $60 \%$ of sand hoppers in the sample survived soon after trampling, but could not survive more than $24 \mathrm{~h}$ after the experiment.

Decapods are indicators used to assess trampling impacts $[55,56]$. Burrow counting has been used in most of the cases when crabs are used as indicators to analyze the impacts of beach activities. A couple of studies demonstrated lower burrow density at trampled plots with more significant impacts on large sized burrows by simulating pedestrian trampling [57-59]. The burrow density and size were reported to decrease suddenly after trampling but burrow counting may not correspond to the size of the sampled population of crabs. According to Silva and Calado [60], the burrow counts may be challenged by the existence of multiple openings, multiple burrows by the same crab or the "secret chambers", i.e., special chambers made by crabs inside the main burrow to avoid detection. For burrow counting, it must be important to consider the burrowing behavior of the crab, otherwise the results could potentially become biased. The results could also become biased if there are obscured burrow openings [55]. Kim et al. [56] analyzed the effect of trampling on the behavior of intertidal crabs in South Korea by applying three-leveled trampling; no trampling, moderate trampling (i.e., 20 steps), heavy trampling (60 steps). The same trend was reported i.e., with increasing trampling intensity the number of crabs declined, while no crabs returned to the trampled plots even $30 \mathrm{~min}$ after the trampling. Along with beach cleaning, trampling has been found to be an important driver in disappearance of crabs [61]. As mentioned earlier, the understanding of behavior especially of fast-moving organisms is really important here, as mentioned in the paper: the crabs started to hide as the people approached even before trampling. Additionally, since the study was conducted in a conservation area with remarkable crab population and permission was allowed only for specific purpose, still the disappearance of crabs for half an hour after trampling reveals the magnitude of influence on behavior. García-García et al. [62] used the gastropod Cyclope neritea as an indicator of the trampling impacts on macrofauna living in sandy beaches of southern Spain, which displayed very peculiar results. Unlike other species, the density of $C$. neritea was found to be significantly high at the trampled spots, except during flooding periods. C. neritea gastropods stay buried in the sand during low tide, but they are stimulated by the resuspension due to trampling, since it helps them to find food faster [62]. The increase in number of other gastropods with trampling has been reported by Rossi et al. [51] focusing only on juveniles. The study also related the number of $C$. neritea to the ebbing and flooding phenomenon, showing its sensitivity to tidal cycle. The use of $C$. neritea can be a good indicator at beaches with limited use but at urbanized beaches, intensive trampling might be lethal to them, resulting in biased data. 


\subsection{Studies on Breakwater Barriers}

The rising sea level and storm frequency are globally increasing the demand for placement of hard coastal defenses $[63,64]$. But, at the same time, hard structures, such as breakwater barriers, are thought to be weak surrogates of natural habitats [65] and do not fully reach the expected results. These structures influence the sediment transportation by reflection, refraction, diffraction and dissipation of waves [66] and could affect the community structure by physical alterations [67]. However, little has been understood about their impacts on macrofaunal communities in soft-bottom environments.

Among the examined papers on breakwaters, Bertasi et al. [68] has used the term "artificial defence structures"; Martin et al. [69] has referred them as "coastal defence structures", while the most recent two articles $[70,71]$ included the term 'breakwater', showing some uniformity of the term with time.

Three of the four studies about breakwater barriers (Table S1) were conducted entirely in Italy [68,70,71], while one was done collectively in Italy, Spain and England [69]. Out of the four studies in Italy, three were conducted at or nearby the beach 'Lido di Dante', on the northern Adriatic coast, while one was done on Tyrrhenian coast. In all the studies found, the overall macrofaunal community was considered rather than some particular indicator species. The first study focusing on breakwaters' impacts on soft-bottom macrofaunal communities was conducted by Martin et al. [69]. They suggested a difference in the community structure with an increase in macrofaunal diversity at breakwater barriers compared to the control sites and attributed it to the presence of species belonging to the rocky substrate and altered dominance relationship among species. The comparison in the first study was made among landward side, seaward side and a controlled site. At Lido di Dante, the species' number at the landward side was always significantly higher than the seaward and the control sites. Moreover, differences among infaunal abundance at controlled, landward and seaward side were also reported at other locations covered in Spain and UK.

Another study at the same location in Italy, i.e., Lido di Dante, was done on a breakwater connected to land by two groynes making a sheltered location between the breakwater and the shore [68]. This study also considered a comparative analysis of the seaward side, landward side (sheltered) and an adjacent fully exposed reference site. The number of taxa found on landward sheltered site was significantly higher than the other two sites with a dominance of bivalves $(50.8 \%)$ and polychaetes $(43.3 \%)$. Breakwater barriers actually make pools where the environmental conditions are different than the surrounding [70] and could provide favorable ground for new species to thrive. Furthermore, the community composition at landward side was found to be significantly different (50.8\% bivalves, $43.3 \%$ polychaetes) than the seaward (98.3\% bivalves) and reference sites ( $91.6 \%$ bivalves). Just like the shallow northern Adriatic Sea, communities at Lido di Dante are poor in species and the quantitative dominance could be found only in few species [72].

These results were further supported by Munari et al. [70], who conducted a study at a small distance from the site studied by Martin et al. [68] at Lido di Dante. They reported seasonal differences in species on seaward side and not on landward side. Significant differences between landward and seaward side were reported for summer (June) only. For October, some species could be found exclusively either on landward (six species) or seaward (four species) side. The seasonal changes at seaward side and stability at landward side could be possibly related to the fact that breakwaters in the intertidal zone are expected to provide a more homogenous habitat at micro-spatial scale than the natural habitat [73].

Some further advancement was made by Becchi et al. [71], who investigated the ecological impacts of breakwater barriers at two locations by adapting a new strategy. They conducted sampling while considering sample points at different distance from the breakwater, i.e., at 5, 15, 50 and $100 \mathrm{~m}$. The abundant species found were crustaceans, polychaetes and molluscs, while other taxa were found in small percentages. The distance from breakwater did not influence the species' abundance significantly, but the species' composition was affected significantly. A higher level of dissimilarities was reported in macrobenthic assemblages among the study sites, showing the dependence of soft 
bottom communities on specific environments. The response of benthic communities to breakwaters or coastal defense structures could potentially be influenced by local conditions and infrastructure.

\subsection{Studies on Mechanical Beach Cleaning}

Mechanical beach cleaning has been one of the basic concerns for beach managers to satisfy beach visitors. At the same time, the impact of mechanical cleaning practices is one of the most under-investigated topics in beach management [14]. Out of the total eight studies found, two have reported insignificant values for impact resulting from mechanical beach cleaning on macrofaunal population $[74,75]$, while five have favored the argument that mechanical beach cleaning does have a negative impact on macrofauna [59,76-78]. Among the studies conducted, two are using single indicator species, while the rest are comparing multiple species to investigate the problems associated with mechanical beach cleaning. The indicator species used in two studies are the ghost crab (Ocypode cordimanus) [59] and sand hopper (Talitrus saltator) [79].

In studies using the ghost crab, burrow counting has been considered in several studies to analyze human impacts on sandy beaches [61,80]. All the studies found had considered multiple beaches for conducting a comparison of macrofaunal communities or species, based on the frequency or presence and absence of mechanical cleaning activities. Some of the beach organisms like Donax spp. are reported in the literature to be affected mainly through physical injuries from beach vehicular traffic [81,82], while others like talitrid amphipods from the removal of the beach wrack [76]. Most of the authors have associated the wrack or organic matter removal resulting from beach cleaning as a reason for decrease in abundance. Several studies [61,76-79] have reported $25 \%$ more abundant macrofauna, such as amphipods and isopods, on ungroomed beaches compared to the groomed ones, and related it to the macrophyte wrack on the beach. Dugan et al. [76] reported significant differences in species' richness, abundance and biomass due to bottom-up effects of the macrophyte wrack subsidies. Gilburn [77] associated the grooming-driven decline in macrofaunal diversity to beach award status and stated that award beaches are groomed more often (69\% groomed) than non-award beaches ( $6 \%$ groomed). Out of 8 taxa considered as indicators, on average 4.86 could be found on ungroomed beaches, while 1.13 on groomed beaches. The study concluded the beach award status as the major factor in the loss of macrofaunal diversity. Another study [78] also correlated the macrofaunal taxa richness to the depth of wrack and revealed a positive relationship between wrack depth and macrofaunal diversity. In this year-long study at 104 sites, it is also reported that taxa richness is high on ungroomed beaches even in winter, when the wrack depth becomes similar on both groomed and ungroomed beaches. The impact could also be long lasting as a result of other activities, since groomed beaches are the ones which are intensely used by visitors. As an indicator, the ghost crab is another species found to be negatively affected by mechanical beach cleaning and other related beach activities $[59,62,80]$. The relationship between ghost crab density and mechanical beach cleaning has further been explored by Stelling-Wood et al. [59], who found a decline in burrow density of ghost crabs with increase in frequency of mechanical beach cleaning by comparing three beaches with high, medium and low cleaning frequency. The burrow density was found to be higher in beaches cleaned three or less than three times a week. In contrast, a couple of studies did not report significant effects of mechanical beach cleaning on macrofaunal communities [74,75]. No significant impact of cleaning was reported on macrofaunal assemblages in Sweden by Malm et al. [74]; however, the organic matter and total biomass was found to be significantly lower on the intensively cleaned beaches. Among the macrofauna, the polychaetes, mysids and mussels were the most commonly found groups, with abundances significantly higher at uncleaned sites. The study also related the presence of these groups to the decomposing beach casts on uncleaned beaches.

Morton et al. [75] also did not report any significant difference in the community structure (at partially cleaned beaches), but related it to the frequency of cleaning and supplemented the conclusions of Stelling-Wood et al. [59], i.e., the density of organisms declines with an increasing frequency of cleaning and vice versa. Beaches that are cleaned moderately have similar organic matter 
and total animal biomass as uncleaned ones [74], however, more frequent cleaning (more than three days) has been reported to have more prominent impacts [59].

\section{Conclusions}

Considering our findings, we conclude that the work done focusing the impacts of individual three human disturbances, i.e., trampling, installation of breakwater barriers and mechanical beach cleaning, on sandy beach macrofauna is scarce and very region-specific. In our observation, the reason for this limited number of detected studies is that, in most of the cases, the impacts are not evaluated independently and are collectively grouped as human disturbances or human activities, probably due to difficulties in separating them. In the case of trampling, almost all the articles had reported negative impact on benthic macrofauna of sandy beaches. Exceptionally, one article did not report significant impact and justified it with limited trampling pressure on the beach. Almost all of the authors have reported a significant influence of breakwater barriers on benthic macrofauna, whose species composition and abundance were deeply altered. Mechanical beach cleaning was also found to be significantly influencing benthic macrofaunal communities, where 6 out of 8 studies reported a negative impact of cleaning activities. In beach cleaning studies, the species are mostly reported to be affected by direct physical injuries or loss of biomass which they inhabit and exploit.

Among all the three impacts, "breakwater barriers" is the most under-investigated issue. Additionally, there is deficiency of data on the subject in general. Although all the three studies about breakwaters are involving the Mediterranean Sea, the studies on trampling and mechanical beach cleaning have been scarcely conducted in this basin. Similarly, the impacts of breakwaters still need to be investigated in other parts of the world. The studies on trampling impacts are rather uniform with time and had followed comparatively more simplified methods with well-explained scales of impact, such as number of visitors in beaches. However, the studies on mechanical beach cleaning impacts lack information about the magnitude and type of beach cleaning machinery.

We highlighted that the considered impacts affect macrofaunal assemblages-which could be shaped by meiofauna [83], and in its turn, shape the communities feeding on macrofauna, for example, the Kentish plover, Charadrius alexandrinus Linnaeus, 1758 (Chordata, Aves, Charadriiformes), a species included in the Annex I of the Bird Directive 2009/147/EC [84] (Nature 2000 code: A138) and in the International Union for Conservation of Nature (IUCN) Red List of Threatened Species as LC (Least Concern) [85].

The current and generalized engineering approach to protect coasts with breakwaters and the use of beaches for touristic purposes without an ecosystem-based management asks urgently for further studies on their impact on biodiversity of beach ecosystems, especially regarding to breakwater barriers. While dune systems and sandbanks are considered by Habitat Directive [86], the intertidal zone (except for mud- and sandflats) is excluded by environmetnal protection regulations, notwithstanding its priority ecological role in land-sea connectivity [87]. With this paper, we would stress the importance of the intertidal zone, and underline that anthropocentric [88] beach usage is not suitable to maintain the biodiversity and ecosystem functions of this habitat. Further researches on impacts on beach ecosystems should be promoted all around the world to find appropriate macrofauna indicator species and to address a more sustainable use of beaches.

Supplementary Materials: The following are available online at http://www.mdpi.com/2077-1312/8/6/405/s1. Table S1: Main Anthropogenic Impacts on Benthic Macrofauna of Sandy Beaches.

Author Contributions: Conceptualization, C.G.D.C. and C.C.; Methodology, A.A., G.L. and C.G.D.C.; Software, A.A., C.G.D.C., T.P.M, C.R.; Validation, C.C., B.C. and S.P.; Writing-Original draft preparation, A.A. and C.G.D.C.; Writing-Review and editing, all authors; project administration, C.D.C and C.C.; funding acquisition, C.G.D.C and C.C. All authors have read and agreed to the published version of the manuscript.

Funding: This research received no external funding.

Acknowledgments: This research has been supported by UNIVPM RSA 2018.

Conflicts of Interest: The authors declare no conflict of interest. 


\section{References}

1. Short, A.D. The role of wave height, period, slope, tide range and embaymentisation in beach classifications: A review. Rev. Chil. Hist. Nat. 1996, 69, 589-604.

2. Nel, R.; Campbell, E.E.; Harris, L.; Hauser, L.; Schoeman, D.; McLachlan, A.; Du Preez, D.R.; Bezuidenhout, K.; Schlacher, T.A. The status of sandy beach science: Past trends, progress, and possible futures. Estuarine Coast. Shelf Sci. 2014, 150, 1-10. [CrossRef]

3. Parlagreco, L.; Melito, L.; DeVoti, S.; Perugini, E.; Soldini, L.; Zitti, G.; Brocchini, M. Monitoring for Coastal Resilience: Preliminary Data from Five Italian Sandy Beaches. Sensors 2019, 19, 1854. [CrossRef] [PubMed]

4. Huettel, M.; Rusch, A. Transport and degradation of phytoplankton in permeable sediment. Limnol. Oceanogr. 2000, 45, 534-549. [CrossRef]

5. Pacheco, A.S.; González, M.T.; Bremner, J.; Oliva, M.; Heilmayer, O.; Laudien, J.; Riascos, J.M. Functional diversity of marine macrobenthic communities from sublittoral soft-sediment habitats off northern Chile. Helgol. Mar. Res. 2010, 65, 413-424. [CrossRef]

6. Volkenborn, N.; Polerecky, L.; Hedtkamp, S.I.C.; Van Beusekom, J.E.E.; De Beer, D. Bioturbation and bioirrigation extend the open exchange regions in permeable sediments. Limnol. Oceanogr. 2007, 52, 1898-1909. [CrossRef]

7. Defeo, O.; McLachlan, A.; Schoeman, D.; Schlacher, T.A.; Dugan, J.; Jones, A.; Lastra, M.; Scapini, F. Threats to sandy beach ecosystems: A review. Estuarine Coast. Shelf Sci. 2009, 81, 1-12. [CrossRef]

8. Lozoya, J.P.; Sardá, R.; Jiménez, J.A. Beach multi-risk assessment considering ecosystem services and coastal hazards: A tool for ICZM. In Sandy Beaches and Coastal Zone Management. In Proceedings of the Fifth International Symposium on Sandy Beaches, Rabat, Morocco, 19-23 October 2009; pp. 133-134.

9. Sardá, R.; Valls, J.F.; Pintó, J.; Ariza, E.; Lozoya, J.P.; Fraguell, R.M.; Marti, C.; Rucabado, J.; Ramis, J.; Jiménez, J. Towards a new Integrated Beach Management System: The Ecosystem-Based Management System for Beaches. Ocean Coast. Manag. 2015, 118, 167-177. [CrossRef]

10. Fanini, L.; Plaiti, W.; Papageorgiou, N. Environmental education: Constraints and potential as seen by sandy beach researchers. Estuarine Coast. Shelf Sci. 2019, 218, 173-178. [CrossRef]

11. Lucrezi, S.; Esfehani, M.H.; Ferretti, E.; Cerrano, C. The effects of stakeholder education and capacity building in marine protected areas: A case study from southern Mozambique. Mar. Policy 2019, 108, 103645. [CrossRef]

12. Eu 'Proposal for A Directive of The European Parliament and of The Council Establishing a Framework for Maritime Spatial Planning and Integrated Coastal Management'; COM (2013) 133 final, 0074; European Commission: Brussels, Belgium, 2013; pp. 1-3.

13. Reis, R.D.S.; Rizzo, A.E. Human Trampling Effect on Benthic Fauna of Sandy Beaches with Different Intensities of Use in Rio De Janeiro, Brazil. Oecologia Aust. 2019, 23, 28-38. [CrossRef]

14. Zielinski, S.; Botero, C.M.; Yanes, A. To clean or not to clean? A critical review of beach cleaning methods and impacts. Mar. Pollut. Bull. 2019, 139, 390-401. [CrossRef] [PubMed]

15. Dafforn, K.; Glasby, T.M.; Airoldi, L.; Rivero, N.K.; Mayer-Pinto, M.; Johnston, E. Marine urbanization: An ecological framework for designing multifunctional artificial structures. Front. Ecol. Environ. 2015, 13, 82-90. [CrossRef]

16. Pioch, S.; Relini, G.; Souche, J.; Stive, M.; De Monbrison, D.; Nassif, S.; Simard, F.; Allemand, D.; Saussol, P.; Spieler, R.; et al. Enhancing eco-engineering of coastal infrastructure with eco-design: Moving from mitigation to integration. Ecol. Eng. 2018, 120, 574-584. [CrossRef]

17. Morris, R.L.; Heery, E.C.; Loke, L.H.; Lau, E.; Strain, E.M.; Airoldi, L.; Alexander, K.A.; Bishop, M.J.; Coleman, R.A.; Cordell, J.R.; et al. Design Options, Implementation Issues and Evaluating Success of Ecologically Engineered Shorelines. In Oceanography and Marine Biology; Informa UK Limited: London, UK, 2019; pp. 169-228.

18. Davenport, J.; Davenport, J.L. The impact of tourism and personal leisure transport on coastal environments: A review. Estuarine Coast. Shelf Sci. 2006, 67, 280-292. [CrossRef]

19. Schlacher, T.A.; Thompson, L.; Price, S. Vehicles versus conservation of invertebrates on sandy beaches: Mortalities inflicted by off-road vehicles on ghost crabs. Mar. Ecol. 2007, 28, 354-367. [CrossRef]

20. McLachlan, A.; Defeo, O.; Jaramillo, E.; Short, A.D. Sandy beach conservation and recreation: Guidelines for optimising management strategies for multi-purpose use. Ocean Coast. Manag. 2013, 71, 256-268. [CrossRef] 
21. Machado, P.M.; Suciu, M.C.; Costa, L.L.; Tavares, D.C.; Zalmon, I.R. Tourism impacts on benthic communities of sandy beaches. Mar. Ecol. 2017, 38, e12440. [CrossRef]

22. Cardoso, R.; Barboza, C.A.; Skinner, V.B.; Cabrini, T.M. Crustaceans as ecological indicators of metropolitan sandy beaches health. Ecol. Indic. 2016, 62, 154-162. [CrossRef]

23. Reyes-Martínez, M.J.; Ruíz-Delgado, M.C.; Sanchez-Moyano, J.E.; Garcia-García, F.J. Response of intertidal sandy-beach macrofauna to human trampling: An urban vs. natural beach system approach. Mar. Environ. Res. 2015, 103, 36-45. [CrossRef]

24. Aller, R. Benthic fauna and biogeochemical processes in marine sediments: The role of burrow structures. In Nitrogen Cycling in Coastal Marine Environments; Blackburn, T.H., Sørensen, J., Eds.; John Wiley \& Sons Ltd.: Chichester, UK, 1988; pp. 301-338.

25. Kristensen, E.; Penha-Lopes, G.; Delefosse, M.; Valdemarsen, T.; Quintana, C.O.; Banta, G.T. What is bioturbation? The need for a precise definition for fauna in aquatic sciences. Mar. Ecol. Prog. Ser. 2012, 446, 285-302. [CrossRef]

26. D'Andrea, A.F.; DeWitt, T.H. Geochemical ecosystem engineering by the mud shrimp Upogebia pugettensis (Crustacea: Thalassinidae) in Yaquina Bay, Oregon: Density-dependent effects on organic matter remineralization and nutrient cycling. Limnol. Oceanogr. 2009, 54, 1911-1932. [CrossRef]

27. Constable, A.J. Ecology of benthic macro-invertebrates in soft-sediment environments: A review of progress towards quantitative models and predictions. Austral Ecol. 1999, 24, 452-476. [CrossRef]

28. Carvalho, A.N.; Pereira, F.; Bosnic, I.; Taborda, R.; Drago, T.; Gaspar, M.B. Sedimentary dynamics and benthic macrofauna distribution: Insights from the shoreface in southern Portugal. J. Sea Res. 2018, 137, 9-25. [CrossRef]

29. Borja, A.; Franco, J.; Pérez, V. A Marine Biotic Index to Establish the Ecological Quality of Soft-Bottom Benthos Within European Estuarine and Coastal Environments. Mar. Pollut. Bull. 2000, 40, 1100-1114. [CrossRef]

30. Muxika, I.; Borja, A.; Bald, J. Using historical data, expert judgement and multivariate analysis in assessing reference conditions and benthic ecological status, according to the European Water Framework Directive. Mar. Pollut. Bull. 2007, 55, 16-29. [CrossRef]

31. Burnett, N.P.; Sarà, G. Functional responses of intertidal bivalves to repeated sub-lethal, physical disturbances. Mar. Environ. Res. 2019, 147, 32-36. [CrossRef]

32. Bessa, F.; Cunha, D.; Gonçalves, S.; Marques, J.C. Sandy beach macrofaunal assemblages as indicators of anthropogenic impacts on coastal dunes. Ecol. Indic. 2013, 30, 196-204. [CrossRef]

33. Bessa, F.; Gonçalves, S.; Franco, J.N.; André, J.N.; Cunha, P.P.; Marques, J.C. Temporal changes in macrofauna as response indicator to potential human pressures on sandy beaches. Ecol. Indic. 2014, 41, 49-57. [CrossRef]

34. Veloso, V.G.; Silva, E.S.; Caetano, C.H.S.; Cardoso, R.S. Comparison between the macroinfauna of urbanized and protected beaches in Rio de Janeiro State, Brazil. Boil. Conserv. 2006, 127, 510-515. [CrossRef]

35. Veloso, V.G.; Neves, G.; Lozano, M.; Perez-Hurtado, A.; Gago, C.G.; Hortas, F.; Garcia-García, F.J. Responses of talitrid amphipods to a gradient of recreational pressure caused by beach urbanization. Mar. Ecol. 2008, 29, 126-133. [CrossRef]

36. Veloso, V.G.; Sallorenzo, I.A.; Ferreira, B.C.A.; De Souza, G.N. Atlantorchestoidea brasiliensis (Crustacea: Amphipoda) as an indicator of disturbance caused by urbanization of a beach ecosystem. Braz. J. Oceanogr. 2010, 58, 13-21. [CrossRef]

37. Wright, L.; Short, A. Morphodynamic variability of surf zones and beaches: A synthesis. Mar. Geol. 1984, 56, 93-118. [CrossRef]

38. Dexter, D.M. Sandy Beach Community Structure: The Role of Exposure and Latitude. J. Biogeogr. 1992, 19, 59. [CrossRef]

39. Barboza, F.R.; Defeo, O. Global diversity patterns in sandy beach macrofauna: A biogeographic analysis. Sci. Rep. 2015, 5, 14515. [CrossRef] [PubMed]

40. Thrush, S.F.; Hewitt, J.E.; Kraan, C.; Lohrer, A.M.; Pilditch, C.A.; Douglas, E. Changes in the location of biodiversity-ecosystem function hot spots across the seafloor landscape with increasing sediment nutrient loading. Proc. R. Soc. B Boil. Sci. 2017, 284, 20162861. [CrossRef]

41. Löffler, M.; Coosen, J. Ecological Impact of Sand Replenishment; Healy, M.G., Doody, J.P., Eds.; Directions in European Coastal Management. Samara Publishing Ltd.: Cardigan, UK, 1995; Volume 14, pp. pp. 291-299.

42. Greene, K. Beach Nourishment: A review of the biological and physical impacts; ASMFC Habitat Management Series \#7; Atlantic States Marine Fisheries Commission: Washington DC, USA, 2002; p. 174. 
43. Speybroeck, J.; Bonte, D.; Courtens, W.; Gheskiere, T.; Grootaert, P.; Maelfait, J.-P.; Mathys, M.; Provoost, S.; Sabbe, K.; Stienen, V.V.L.; et al. Beach nourishment: an ecologically sound coastal defence alternative? A Rev. Aquat. Conserv. 2006, 16, 419-435. [CrossRef]

44. Leewis, L.; van Bodegom, P.M.; Rozema, J.; Janssen, G.M. Does beach nourishment have long-term effects on intertidal macoinvertebrate species abundance? Estuar. Coast. Shelf Sci. 2012, 113, 172-181. [CrossRef]

45. Witmer, A.D.; Bell, A.C.; Ammons, A.W. Examination of intertidal and nearshore benthic macroinvertebrates along two non-nourished Florida beaches. Reg. Stud. Mar. Sci. 2019, 27, 100548. [CrossRef]

46. Costa, L.L.; Tavares, D.C.; Suciu, M.C.; Rangel, D.F.; Zalmon, I.R. Human-induced changes in the trophic functioning of sandy beaches. Ecol. Indic. 2017, 82, 304-315. [CrossRef]

47. Fanini, L.; Zampicinini, G.; Pafilis, E. Beach parties: A case study on recreational human use of the beach and its effects on mobile arthropod fauna. Ethol. Ecol. Evol. 2013, 26, 69-79. [CrossRef]

48. Jaramillo, E.; Contreras, H.; Quijon, P. Macroinfauna and human disturbance in a sandy beach of south-central Chile. Rev. Chil. Hist. Nat. 1996, 69, 655-663.

49. Wynberg, R.; Branch, G.M. Trampling associated with bait-collection for sandprawns Callianassa kraussi Stebbing: Effects on the biota of an intertidal sandflat. Environ. Conserv. 1997, 24, 139-148. [CrossRef]

50. Moffett, M.D.; McLachlan, A.; Winter, P.E.D.; De Ruyck, A.M.C. Impact of trampling on sandy beach macrofauna. J. Coast. Conserv. 1998, 4, 87-90. [CrossRef]

51. Rossi, F.; Forster, R.; Montserrat, F.; Ponti, M.; Terlizzi, A.; Ysebaert, T.; MiddelburgiD, J. Human trampling as short-term disturbance on intertidal mudflats: Effects on macrofauna biodiversity and population dynamics of bivalves. Mar. Boil. 2007, 151, 2077-2090. [CrossRef]

52. Schlacher, T.A.; Thompson, L. Beach recreation impacts benthic invertebrates on ocean-exposed sandy shores. Boil. Conserv. 2012, 147, 123-132. [CrossRef]

53. Schlacher, T.A.; Carracher, L.K.; Porch, N.; Connolly, R.M.; Olds, A.D.; Gilby, B.L.; Ekanayake, K.B.; Maslo, B.; Weston, M.A. The Early Shorebird Will Catch Fewer Invertebrates on Trampled Sandy Beaches. PLoS ONE 2016, 11, e0161905. [CrossRef]

54. Ugolini, A.; Ungherese, G.; Somigli, S.; Galanti, G.; Baroni, D.; Borghini, F.; Cipriani, N.; Nebbiai, M.; Passaponti, M.; Focardi, S. The amphipod Talitrus saltator as a bioindicator of human trampling on sandy beaches. Mar. Environ. Res. 2008, 65, 349-357. [CrossRef]

55. Lucrezi, S.; Schlacher, T.A.; Robinson, W. Human disturbance as a cause of bias in ecological indicators for sandy beaches: Experimental evidence for the effects of human trampling on ghost crabs (Ocypode spp.). Ecol. Indic. 2009, 9, 913-921. [CrossRef]

56. Kim, T.W.; Kim, S.; Lee, J.-A. Effect of Mudflat Trampling on Activity of Intertidal Crabs. Ocean Sci. J. 2018, 53, 101-106. [CrossRef]

57. Barros, F. Ghost crabs as a tool for rapid assessment of human impacts on exposed sandy beaches. Boil. Conserv. 2001, 97, 399-404. [CrossRef]

58. Noriega, R.; Schlacher, T.A.; Smeuninx, B. Reductions in Ghost Crab Populations Reflect Urbanization of Beaches and Dunes. J. Coast. Res. 2012, 279, 123-131. [CrossRef]

59. Stelling-Wood, T.P.; Clark, G.F.; Poore, A.G.B. Responses of ghost crabs to habitat modification of urban sandy beaches. Mar. Environ. Res. 2016, 116, 32-40. [CrossRef] [PubMed]

60. Silva, W.T.; Calado, T. Number of ghost crab burrows does not correspond to population size. Open Life Sci. 2013, 8, 843-847. [CrossRef]

61. Ocaña, F.A.; Navarrete, A.D.J.; Navarrete, R.M.D.J.; Rivera, J.J.O. Efectos del disturbio humano sobre la dinámica poblacional de Ocypode quadrata (Decapoda: Ocypodidae) en playas del Caribe mexicano. Revista de Biología Tropical 2016, 64, 1625-1641. [CrossRef]

62. Garcia-García, F.J.; Reyes-Martínez, M.J.; Ruiz-Delgado, M.C.; Sanchez-Moyano, J.E.; Casas, M.C.; Perez-Hurtado, A. Does the gathering of shellfish affect the behavior of gastropod scavengers on sandy beaches? A field experiment. J. Exp. Mar. Boil. Ecol. 2015, 467, 1-6. [CrossRef]

63. Hall, A.E.; Herbert, R.J.; Britton, J.R.; Hull, S.L. Ecological enhancement techniques to improve habitat heterogeneity on coastal defence structures. Estuarine Coast. Shelf Sci. 2018, 210, 68-78. [CrossRef]

64. Firth, L.; Knights, A.; Bridger, D.; Evans, A.; Mieszkowska, N.; Moore, P.J.; O'Connor, N.; Sheehan, E.; Thompson, R.; Hawkins, S. Ocean Sprawl: Challenges and Opportunities for Biodiversity Management In A Changing World. Oceanogr. Mar. Biol. 2016, 54, 193-270. [CrossRef] 
65. Cacabelos, E.; Martins, G.M.; Thompson, R.; Prestes, A.; Azevedo, J.; Neto, A. Material type and roughness influence structure of inter-tidal communities on coastal defenses. Mar. Ecol. 2016, 37, 801-812. [CrossRef]

66. Jackson, N.L.; Harley, M.D.; Armaroli, C.; Nordstrom, K.F. Beach morphologies induced by breakwaters with different orientations. Geomorphology 2015, 239, 48-57. [CrossRef]

67. Moschella, P.; Abbiati, M.; Aberg, P.; Airoldi, L.; Anderson, J.; Bacchiocchi, F.; Bulleri, F.; Dinesen, G.; Frost, M.; Gacia, E.; et al. Low-crested coastal defence structures as artificial habitats for marine life: Using ecological criteria in design. Coast. Eng. 2005, 52, 1053-1071. [CrossRef]

68. Bertasi, F.; Colangelo, M.A.; Abbiati, M.; Ceccherelli, V.U. Effects of an artificial protection structure on the sandy shore macrofaunal community: The special case of Lido di Dante (Northern Adriatic Sea). Hydrobiologia 2007, 586, 277-290. [CrossRef]

69. Martin, D.; Bertasi, F.; Colangelo, M.A.; De Vries, M.; Frost, M.; Hawkins, S.J.; MacPherson, E.; Moschella, P.S.; Satta, M.P.; Thompson, R.C.; et al. Ecological impact of coastal defence structures on sediment and mobile fauna: Evaluating and forecasting consequences of unavoidable modifications of native habitats. Coast. Eng. 2005, 52, 1027-1051. [CrossRef]

70. Munari, C.; Corbau, C.; Simeoni, U.; Mistri, M. Coastal defence through low crested breakwater structures: Jumping out of the frying pan into the fire? Mar. Pollut. Bull. 2011, 62, 1641-1651. [CrossRef] [PubMed]

71. Becchi, C.; Ortolani, I.; Muir, A.I.; Cannicci, S. The effect of breakwaters on the structure of marine soft-bottom assemblages: A case study from a North-Western Mediterranean basin. Mar. Pollut. Bull. 2014, 87, 131-139. [CrossRef]

72. Lamberti, A.; Zanuttigh, B. An integrated approach to beach management in Lido di Dante, Italy. Estuarine Coast. Shelf Sci. 2005, 62, 441-451. [CrossRef]

73. Aguilera, M.A.; Broitman, B.R.; Thiel, M. Spatial variability in community composition on a granite breakwater versus natural rocky shores: Lack of microhabitats suppresses intertidal biodiversity. Mar. Pollut. Bull. 2014, 87, 257-268. [CrossRef]

74. Malm, T.; Råberg, S.; Fell, S.; Carlsson, P. Effects of beach cast cleaning on beach quality, microbial food web, and littoral macrofaunal biodiversity. Estuarine Coast. Shelf Sci. 2004, 60, 339-347. [CrossRef]

75. Morton, J.K.; Ward, E.J.; De Berg, K.C. Potential Small- and Large-Scale Effects of Mechanical Beach Cleaning on Biological Assemblages of Exposed Sandy Beaches Receiving Low Inputs of Beach-Cast Macroalgae. Chesap. Sci. 2015, 38, 2083-2100. [CrossRef]

76. Dugan, J.E.; Hubbard, D.M.; McCrary, M.D.; Pierson, M.O. The response of macrofauna communities and shorebirds to macrophyte wrack subsidies on exposed sandy beaches of southern California. Estuarine Coast. Shelf Sci. 2003, 58, 25-40. [CrossRef]

77. Gilburn, A. Mechanical grooming and beach award status are associated with low strandline biodiversity in Scotland. Estuarine Coast. Shelf Sci. 2012, 107, 81-88. [CrossRef]

78. Griffin, C.; Day, N.; Rosenquist, H.; Wellenreuther, M.; Bunnefeld, N.; Gilburn, A. Tidal range and recovery from the impacts of mechanical beach grooming. Ocean Coast. Manag. 2018, 154, 66-71. [CrossRef]

79. Fanini, L.; Cantarino, C.M.; Scapini, F. Relationships between the dynamics of two Talitrus saltator populations and the impacts of activities linked to tourism. Oceanologia 2005, 47, 93-112.

80. De Souza, G.N.; Oliveira, C.A.; Tardem, A.S.; Soares-Gomes, A. Counting and measuring ghost crab burrows as a way to assess the environmental quality of beaches. Ocean Coast. Manag. 2017, 140, 1-10. [CrossRef]

81. Van der Merwe, D.; Van der Merwe, D. Effects of off-road vehicles on the macrofauna of a sandy beach. S. Afr. J. Sci. S. Afr. Tydskr. Wet. 1991, 87, 210-213.

82. Schlacher, T.A.; Thompson, L.M.C. Physical Impacts Caused by Off-Road Vehicles to Sandy Beaches: Spatial Quantification of Car Tracks on an Australian Barrier Island. J. Coast. Res. 2008, 2, 234-242. [CrossRef]

83. Watzin, M.C. The effects of meiofauna on settling macrofauna: Meiofauna may structure macrofaunal communities. Oecologia 1983, 59, 163-166. [CrossRef]

84. Directive 2009/147/EC of the European Parliament and of the Council of 30 November 2009 on the Conservation of Wild Birds OJ L 20, 26.1.2010. pp. 7-25. Available online: https://eur-lex.europa.eu/legal-content/EN/NIM/ ?uri=CELEX:32009L0147 (accessed on 25 May 2020).

85. Iucn Charadrius alexandrinus: BirdLife International. IUCN Red List Threat. Species 2016. [CrossRef]

86. Directive, H. Council Directive 92/43/EEC of 21 May 1992 on the conservation of natural habitats and of wild fauna and flora. Off. J. Eur. Union 1992, 206, 7-50. 
87. Fang, X.; Hou, X.; Li, X.; Hou, W.; Nakaoka, M.; Yu, X. Ecological connectivity between land and sea: A review. Ecol. Res. 2017, 33, 51-61. [CrossRef]

88. Kopnina, H.; Washington, H.; Taylor, B.; Piccolo, J.J. Anthropocentrism: More than Just a Misunderstood Problem. J. Agric. Environ. Ethic 2018, 31, 109-127. [CrossRef]

(C) 2020 by the authors. Licensee MDPI, Basel, Switzerland. This article is an open access article distributed under the terms and conditions of the Creative Commons Attribution (CC BY) license (http://creativecommons.org/licenses/by/4.0/). 